\title{
Induction of anaes- thesia with etomidate in a patient with acute intermittent porphyria
}

This is a case report of a 35-year-old female with acute intermittent porphyria who presented for elective vagotomy and pyloroplasty. The diagnosis of porphyria was made two years previously when she developed acute abdominal pain and lower motor neurone paralysis following ingestion of a barbiturate. The urine porphobilinagen test was pasitive. The parient had no other acute attack of porphyria and had not had a previous anaesthetic.

Anaesthesia was induced with etomidate $0.3 \mathrm{mg} \cdot \mathrm{kg}^{-1}$ IV. Muscle relaxation was obtained with pancuronium $6 \mathrm{mg} I V$ and ventilation was mechanically controlled. Intraoperative analgesia was with 66 per cent nirrous oxide in oxygen and intermittent doses of fentanyl. The patient was stable during anaesthesia and surgery.

The postoperative period was uneventful and patient did not have an acute attack of porphyria. This experience suggests that etomidate is safe for intravenous induction of anaesthesia in acute intermittent porphyria. However, reports of its use in more patients with this disease will be necessary before a final conclusion can be made.

\section{Key words}

ANAESTHETICS INTRAVENOUS: etomidate; GENETIC FACTORS: porphyria.

From the Department of Anaesthesia, College of Medicine, University of Ibadan, Ibadan, Nigeria. Address correspondence to: Dr. C.E. Famewo, Department of Anaesthesiology, King Fahd Hospital of the University, P.O. Box 2208, Al-Khobar, Saudi Arabia.
Acute intermittent porphyria is an uncommon familial disease transmitted as a Mendelian dominant gene. The implication to the anaesthetist is the limitation it imposes on his choice of anaesthetic drugs, especially those for intravenous induction of anaesthesia. The more commonly used intravenous anaesthetic induction agents, the barbiturates thiopentone and methohexitone are contraindicated. This report of the safe use of etomidate in a patient with acute intermittent porphyria therefore merits attention as this has not been previously reported.

\section{Case report}

A 35 -year-old female weighing $52 \mathrm{~kg}$ with acute intermittent porphyria was admitted for elective vagotomy and pyloroplasty. The diagnosis of porphyria was made two years previous to the present admission. At that time she developed acute abdominal pain and lower motor neurone paralysis following ingestion of a barbiturate. Examination of the urine for porphyrins confirmed the diagnosis of acute intermittent prophyria - a positive porphobilinogen test.

Following recovery from this attack patient was given a list of drugs to avoid. She has had no other acute attack of porphyria and she had not had a previous anaesthetic.

At the time of the present admission the patient had no symptoms of an acute attack of porphyria. Clinical examination of the cardiovascular, respiratory and nervous systems were normal. The haematocrit was 36 per cent while the serum electrolytes and urea were normal.

The patient had premedication with meperidine $50 \mathrm{mg} \mathrm{IM}$ about 45 minutes prior to induction of anaesthesia. After five minutes of pre-oxygenation, $0.6 \mathrm{mg}$ atropine was given intravenously and anaes- 
thesia induced with etomidate $0.3 \mathrm{mg} \cdot \mathrm{kg}^{-1}$ body weight. Succinylcholine $75 \mathrm{mg}$ IV was given to facilitate endotracheal intubation while pancuronium $6 \mathrm{mg}$ IV was given to provide relaxation for surgery. Analgesia was maintained with 66 per cent nitrous oxide in oxygen, and intermittent doses of fentanyl. Surgery lasted about one hour during which time the patient's vital signs remained stable. Blood loss was less than $400 \mathrm{ml}$. She did not require blood transfusion but received $500 \mathrm{ml}$ of five per cent dextrose in water and $350 \mathrm{ml}$ of normal saline. At the end of surgery neostigmine $2.5 \mathrm{mg}$ and atropine $1.2 \mathrm{mg}$ were given intravenously to reverse the effect of the muscle relaxant.

On arrival in the recovery room the patient was rousable, blood pressure was normal, peripheral circulation was good, respiration was satisfactory and she could move all limbs.

The postoperative period was uneventful and patient did not have an attack of porphyria.

\section{Discussion}

Acute intermittent porphyria was first described by Schultz in 1974 and was so named by Stokvis, ' a Dutch physician in 1889 . It is a relatively rare disorder though seen more often in Sweden. It is inherited in an autosomal dominant pattern with a variable phenotypic expression. This congenital metabolic defect is characterised in its active phase by urine which turns red or brown on standing. The porphobilinogen reaction to urine is always positive during relapse but it may not necessarily be positive during remission.

Acute attacks may arise de novo or may be precipitated by infection, pregnancy or drugs, including some anaesthetic agents. The clinical features of acute porphyria are many and varied. Gastrointestinal symptoms include acute abdominal pain, constipation and vomiting. Cardiovascular symptoms include tachycardia and hypertension. Neurological features include seizures, paraplegia or quadriplegia, bulbar paralysis, peripheral neuropathy, psychosis, depresion and coma. There may be residual paresis after an attack.

The pathological picture is that of widespread demyelinization of the central and peripheral nervous systems. Demyelinization is thought to result from the associated high levels of the hepatic enzyme-aminolevulinic acid (ALA) synthetase.
Drugs or anaesthetic agents that stimulate hepatic ALA synthetase production can therefore trigger an attack. $^{2,3}$

The implication of acute intermittent porphyria to the anaesthetist is the restriction it imposes on his choice of anaesthetic drugs, especially intravenous induction agents. Drugs that have been reported to be unsafe for intravenous induction of anaesthesia in patients with acute intermittent porphyria include thiopentone ${ }^{4}$ and methohexitone (barbiturates), althesin and diazepam (benzodiazepine). ${ }^{5,6} \mathrm{Re}$ ported safe intravenous anaesthetic induction agents include propanidid and ketamine. ${ }^{5,7,8}$ Etomidate, an imidazole carboxylate derivative, has undergone clinical trials in the recent past. ${ }^{9}$ Its use in acute intermittent porphyria has however not been reported. Clinical trials with etomidate have shown good cardiovascular and respiratory stability and a wide margin of safety. The drug is rapidly metabolised in the plasma and patients do not have a hangover effect. The main disadvantages of etomidate are the pain experienced by a significant number of patients during intravenous injection of the drug (incidence of 13 to 40 per cent), and myoclonic movement seen following induction (incidence of 32 per cent). The incidence of pain can be reduced by using the larger veins of the forearm or using a preparation with a less acidic $\mathrm{pH}$. The myoclonic movements are not associated with any postoperative sequelae.

Based on this case report, etomidate would appear to be a safe intravenous anaesthetic induction agent in acute intermittent porphyria. However, reports on its use in more patients with this disease are still needed for a definitive conclusion.

\section{References}

I Stokvis BJE. Ned. Tijdschr., Geneesk 89; 25: 409.

2 Meas DE Jr, Frederickson EL. Anaesthesia and the porphyrias. South Afr Med J 1975; 68: 2932.

3 Mayer UA, Schmid $R$. Hereditary hepatic porphyria. Fed Proc 1973; 32: 1649-53.

4 Mustajoki P, Heinonen J. General anesthesia in "inducible" porphyrias. Anesthesiology 1980; 53: 15-20.

$5 \mathrm{Katz} J$, Benumof $J$, Kadis LB. Anaesthesia and Uncommon Diseases, 2nd Edition. Philadelphia, Churchill Davidson 1978, pp. 23-31. 
6 Parikh RK, Moore MR. Anaesthesia in porphyria: intravenous induction agents. Br J Anaesth 1975; 47: 907.

7 Rizk SF, Jacobson $J H$. Silvay $G$. Ketamine as an induction agent for acute intermittent porphyria Anesthesiology 1977; 46: 305-6.

8 Bankcroft GH, Lauria JI. Ketamine induction for Caesarian section in a patient with acute intermittent porphyria and achondroplastic dwarfism. Anesthesiology 1983; 59: 143-4.

9 Famewo $C E$, Odugbesan $C O$. Further experience with etomidate. Its place in clinical anaesthesia. Can Anaesth Soc J 1978; 25: 130-2.
Résumé

Ceci est l'histoire du cas d'une femme âgée de 35 ans atteinte de porphyrie intermittente aiguë se présentant pour vagotomie et pyloroplastie élective. Le diagnostic de porphyrie a été fait il y a deux ans quand elle a développé une douleur abdominate aiguë et une paralysie motrice du neurone périphérique suite à l'ingestion de barbituriques. Le test du porphobilinogène urinaire était positif. La patiente n' a jamais eu aucune autre attaque de porphyrie et n'a jamais eu d'anesthésie.

L'anesthésie a été induite avec l'éromidate $0.3 \mathrm{mg} \cdot \mathrm{kg}^{-1}$ IV. La relaxation musculaire lors de la chirurgie était obtenue par le pancuronium $6 \mathrm{mg} I \mathrm{~V}$ et la ventilation était contrôlée mécaniquement. L'analgésie intra-opératoire était assurée avec 66 pour cent de protoxyde d' azote dans l'oxygène et des doses intermittentes de fentanyl. La patiente était stable pendant l'anesthésie et la chirurgie.

La période post-opératoire a été sans incidens et la patiente n'a accusé aucune ataque de porphyrie aiguë. Se basant sur ce rapport, l' étomidate apparaît sécuritaire pour une induction anesthésique intraveineuse dans les cas de porphyrie intermittente aiguë. Cependant. d'autres rapports sur son utilisation chez des patients atteints de cette maladie sont encore nécessaires afin de tirer des conclusions définitives. 